Supplement of Atmos. Chem. Phys., 16, 14891-14908, 2016

http://www.atmos-chem-phys.net/16/14891/2016/

doi:10.5194/acp-16-14891-2016-supplement

(C) Author(s) 2016. CC Attribution 3.0 License.

(c) (1)

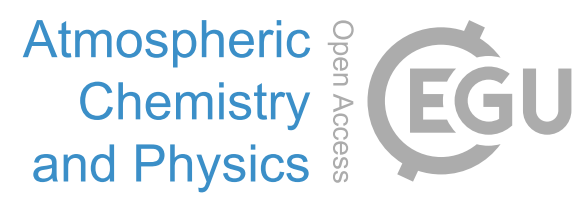

Supplement of

\title{
Using $\delta^{13} \mathbf{C}-\mathrm{CH}_{4}$ and $\delta \mathrm{D}-\mathrm{CH}_{4}$ to constrain Arctic methane emissions
}

Nicola J. Warwick et al.

Correspondence to: Nicola J. Warwick (nicola.warwick@atm.ch.cam.ac.uk)

The copyright of individual parts of the supplement might differ from the CC-BY 3.0 licence. 


\section{Supplementary Material}

\section{Further details on the p-TOMCAT BASE scenario}

The kinetic isotope effects for the methane reaction rates used in the model are listed in Table S1.. Prescribed surface methane fluxes from anthropogenic sources are taken from EDGAR v4.1 (http://edgar.jrc.ec.europa.eu/overview.php?v=41)

5 for 2005. A seasonal variation has been applied to the EDGAR v4.1 fossil fuel source, following Gurney et al. (2005). Biomass burning emissions are taken from a GFEDv2 climatological average (Van der Werf et al. 2006), and are scaled to $31 \mathrm{Tg} \mathrm{yr}^{-1}$. The geographical and temporal distribution of natural methane emissions from termites, hydrates and wetlands is taken from Fung et al. (1991). Tropical and mid-latitude wetland emissions $\left(<50^{\circ} \mathrm{N}\right.$ ) are scaled to $200 \mathrm{Tg} \mathrm{yr}^{-1}$ (wetland emissions $>50^{\circ} \mathrm{N}$ are left unscaled). Table $\mathrm{S} 2$ also shows the source-specific $\delta^{13} \mathrm{C}$ and $\delta \mathrm{D}$ signatures used in the model. As

10 for the fluxes, the isotopic signatures used are all subject to a level of uncertainty. Measurements of source $\delta \mathrm{D}$ signatures are currently much more limited than the $\delta^{13} \mathrm{C}$ signatures and are therefore there is less information about how they vary with source type and region. Out of the $\delta^{13} \mathrm{C}$ source signatures, there is a large uncertainty associated with the $\delta^{13} \mathrm{C}$ isotopic signature of methane emissions to the atmosphere from subsea permafrost and hydrates. This is discussed in Section 6.3. Observations also suggest a wide geographical spread in the $\delta^{13} \mathrm{C}$ signature of emissions from the coal industry (e.g. Zazzeri 15 et al. 2015). In the results presented, we have used a $\delta^{13} \mathrm{C}$ signature for emissions from the coal industry of $-50 \%$. However, simulations in which emissions were assigned $\delta^{13} \mathrm{C}$ values of both $-35 \%$ and $-40 \%$ only had a small impact on the modelled distribution relative to using $-50 \%$ and did not influence our conclusions.

Figure S1 shows a comparison of modelled and observed seasonal cycles of methyl chloroform from the NOAA-ESRL halocarbons in situ program at Barrow, Alaska, indicating that the seasonal cycle of the model prescribed OH concentrations

20 is well represented in the Arctic region.

\section{References}

Bergamaschi, P., Bräunlich, M., Marik, T., and Brenninkmeijer, C. A. M.: Measurements of the carbon and hydrogen isotopes of atmospheric methane at Izaña, Tenerife: Seasonal cycles and synoptic-scale variations, J. Geophys. Res., 105(D11), 14531-14546, doi:10.1029/1999JD901176, 2000.

25 Crowley, J. N., Saueressig, G., Bergamaschi, P., Fischer, H. and Harris, G. W.: Carbon kinetic isotope effect in the reaction $\mathrm{CH} 4+\mathrm{Cl}$ : a relative rate study using FTIR spectroscopy, Chemical Physics Letters, 303, 268-274, 1999.

DeMore, W. B., Rate constant ratio for the reaction of OH with CH3D and CH4, J. Phys. Chem., 97, 8564-8566, 1993.

Fung, I., John, J., Lerner, J., Matthews, E., Prather, M., Steele, L. P., and Fraser, P. J.: Three-dimensional model synthesis of the global methane cycle, J. Geophys. Res., 96, 13033-13065, doi:10.1029/91JD01247, 1991. 
Gierczak, T., Talukdar, R. K., Herndon, S. C., Vaghjiani, G. L., and Ravishankara, A. R.: Rate Coefficients for the Reactions of Hydroxyl Radicals with Methane and Deuterated Methanes, The Journal of Physical Chemistry, 101 (17), 3125-3134, doi: 10.1021/jp963892r, 1997.

Gurney, K. R., Chen, Y.-H., Maki, T., Kawa, S. R., Andrews, A., and Zhu, Z.: Sensitivity of atmospheric CO $\mathrm{CO}_{2}$ inversions to

5 seasonal and interannual variations in fossil fuel emissions, J. Geophys. Res., 110, D10308, doi:10.1029/2004JD005373, 2005.

Saueressig, G., Bergamaschi, P., Crowley, J. N., Fischer, H., Harris, G. W., Carbon kinetic isotope effect in the reaction of CH4 with Cl atoms, Geophys. Res. Lett., 22, 1225-1228, doi: 10.1029/95GL00881, 1995.

Saueressig, G., Bergamaschi, P., Crowley, J. N., Fischer, H., Harris, G. W.: D/H kinetic isotope effect in the reaction 10 CH4+Cl, Geophys. Res., 23, 3619-3622, doi: 10.1029/96GL03292, 1996.

Saueressig, G., Crowley, J. N., Bergamaschi, P., Brühl, C., Brenninkmeijer, C. A. M. and Fischer, H.: Carbon 13 and D kinetic isotope effects in the reactions of $\mathrm{CH} 4$ with $\mathrm{O}(1 \mathrm{D})$ and $\mathrm{OH}$ : New laboratory measurements and their implications for the isotopic composition of stratospheric methane, J. Geophys. Res., 106(D19), 23127-23138, doi:10.1029/2000JD000120, 2001 .

15 Snover, A. K., and Quay, P. D.: Hydrogen and carbon kinetic isotope effects during soil uptake of atmospheric methane, Global Biogeochem. Cycles, 14(1), 25-39, doi:10.1029/1999GB900089, 2000.

Tyler, S. C., Rice, A. L. and Ajie, H. O.: Stable isotope ratios in atmospheric CH4: Implications for seasonal sources and sinks, J. Geophys. Res., 112, D03303, doi:10.1029/2006JD007231, 2007.

Van der Werf, G. R., Randerson, J. T., Giglio, L., Collatz, G. J., Kasibhatla, P. S., and Arellano, Jr., A. F.: Interannual

20 variability in global biomass burning emissions from 1997 to 2004, Atmos. Chem. Phys., 6, 3423-3441, 2006.

Zazzeri, G., Lowry, D., Fisher, R. E., France, J. L., Lanoisellé, M. and Nisbet E. G., Plume mapping and isotopic characterisation of anthropogenic methane sources, Atmos. Environ. 110, 151-162, doi:10.1016/j.atmosenv.2015.03.029, 2015. 
Table S1. Kinetic isotope effects for methane sinks in p-TOMCAT

\begin{tabular}{ccc}
\hline Methane Sink & $\mathrm{KIE}^{12 \mathrm{C} / 13 \mathrm{C}}$ & $\mathrm{KIE}^{\mathrm{H} / \mathrm{D}}$ \\
\hline $\mathrm{CH}_{4}+\mathrm{OH}$ & $1.0039^{1}$ & $1.29^{5}$ \\
$\mathrm{CH}_{4}+\mathrm{Cl}$ & $1.066^{2,3, \mathrm{a}}$ & $1.508^{4, \mathrm{a}}$ \\
$\mathrm{CH}_{4}+\mathrm{O}\left({ }^{1} \mathrm{D}\right)$ & $1.013^{1}$ & $1.06^{1}$ \\
Soil Oxidation & $1.018^{6}$ & $1.083^{6}$
\end{tabular}

\footnotetext{
${ }^{1}$ Saueressig et al. (2001), ${ }^{2}$ Saueressig et al. (1995), ${ }^{3}$ Crowley et al. (1999), ${ }^{4}$ Saueressig et al. (1996), ${ }^{5}$ This value is within a range of quoted literature values (DeMore et al., 1993, Gierczak et al., 1997, Saueressig et al. 2001, Bergamaschi et al., 2000, Tyler et al., 2007), ${ }^{6}$ Snover et al., (2000), ${ }^{\text {a}}$ Kinetic isotope effects are temperature dependent, the value quoted is for
} $5298 \mathrm{~K}$. 


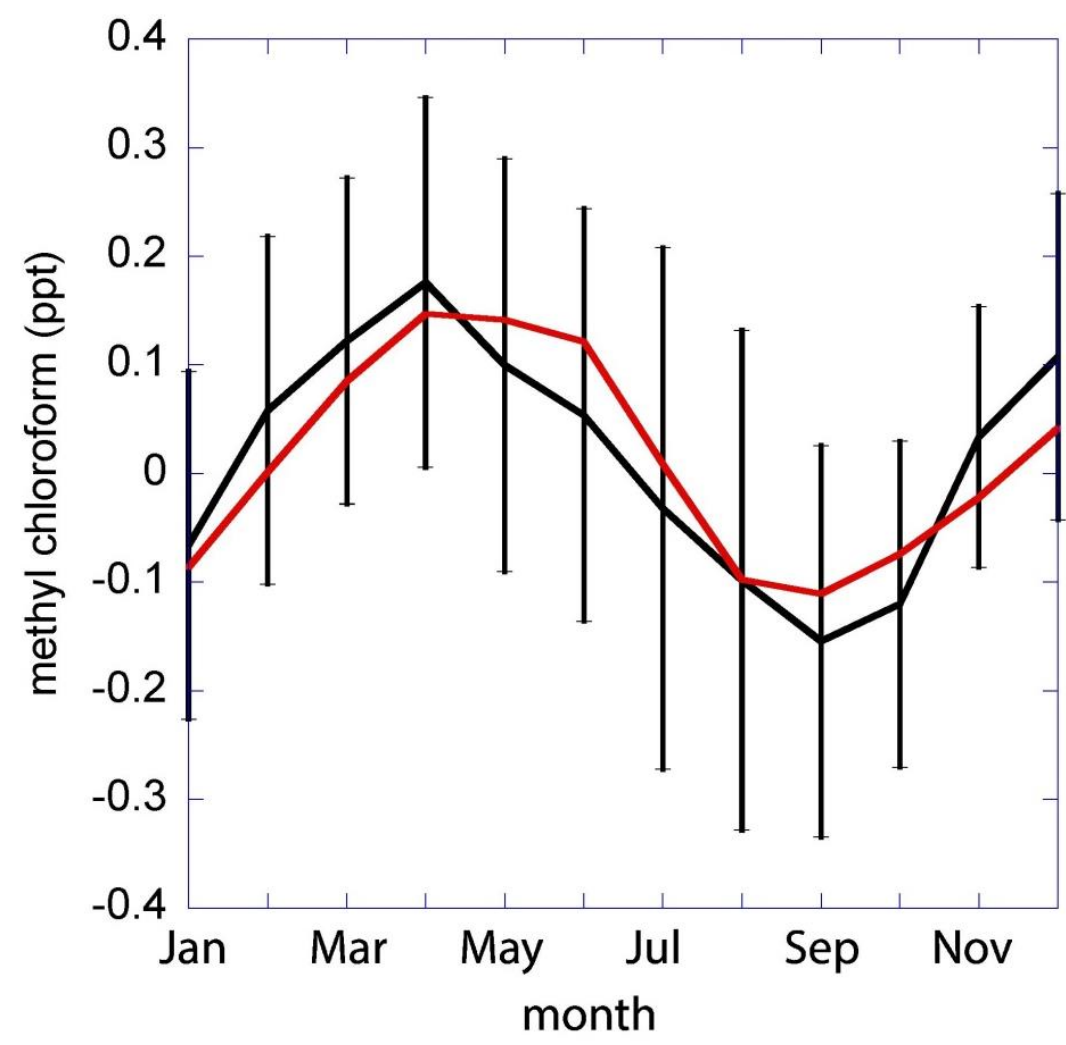

Observed Methyl Chloroform / ppt

Modelled Methyl Chloroform / ppt

Figure S1: A comparison of observed and modelled seasonal cycles for methyl chloroform at Barrow, Alaska $\left(157^{\circ} \mathrm{W}, 7^{\circ} \mathrm{N}\right)$. NOAA-ESRL observations are shown in black and are for the year 2009; error bars show +/- 1 s.d.. Model data uses 2009 meteorology and is shown in red. Linear trends and annual mean mixing ratios have been removed from both the observational and modelled data. 